\title{
COMBINATION OF ENZYMATIC, MECHANICAL AND ULTRASONIC TREATMENTS FOR IMPROVEMENT OF THE PROPERTIES OF SECONDARY PULPS
}

\author{
Juliana Cristina da Silva ${ }^{1 *}$, Rubens Chaves de Oliveira ${ }^{1}$, Larisse Ribas Batalha ${ }^{1}$, Mauro Manfredi ${ }^{1}$
}

*Corresponding author: juliana.cristina@ufv.br

\begin{abstract}
This study evaluated the property recovery capability of handsheets formed from secondary fibers by combining different techniques. To attain that, pulps derived from post-consumer cardboard scrap were subjected to various refining intensities respectively in a PFI mill (0, 400, 800 and 1200 revolutions) and ultrasound (0, 10, 20 and 30 minutes), followed by enzymatic treatments with enzymes Cellulase, Hemicellulase, Mixture 1 and Mixture 2 (both mixtures composed of cellulase and hemicellulase). The papermaking potential of the pulps was evaluated by means of physical and mechanical tests on the resulting paper after the relevant treatments. It was found that both the combination of PFI mill refining with enzymatic treatments and the combination of ultrasound with enzymatic treatments were effective in improving paper properties. It was also found that interfiber bonding properties such as tensile index and ring crush strength had greater increases, in relation to the initial pulp, in pulps derived from the combined PFI mill refining with enzymatic treatments. As for intrinsic fiber strength properties, such as tear resistance, had greater increases in pulps derived from the combined ultrasound with enzymatic treatments.
\end{abstract}

Key words: Recycling, paper properties, refining, ultrasound.

\section{COMBINAÇÃO DOS TRATAMENTOS ENZIMÁTICOS, MECÂNICOS E ULTRASSÔNICOS PARA O MELHORAMENTO DAS PROPRIEDADES DE POLPAS SECUNDÁRIAS}

RESUMO: Neste estudo, avaliou-se a capacidade de recuperação das propriedades dos papéis formados a partir de fibras secundárias pela combinação de diferentes técnicas. Para tanto, polpas preparadas a partir de aparas oriundas de papelão pósconsumo foram submetidas a variadas intensidades de refino em moinho PFI (0, 400, 800 e 1200 revoluções) e ultrassom (0, 10,20 e 30 minutos), respectivamente, seguidos pelos tratamentos enzimáticos com enzimas Celulase, Hemicelulase, Mistura 1 e Mistura 2 (ambas as Misturas compostas por celulase e hemicelulase). O potencial papeleiro das polpas foi avaliado a partir de testes físicos e mecânicos realizados em papéis formados pelas polpas submetidas aos tratamentos em questão. Foram verificados que tanto a combinação do refino em moinho PFI com tratamentos enzimáticos quanto à combinação dos tratamentos ultrassônicos e enzimáticos foram eficientes no melhoramento das propriedades dos papéis avaliados e que as propriedades relacionadas às ligações interfibras como índice de tração e resistência ao esmagamento do anel apresentaram maiores incrementos com relação à polpa inicial em polpas oriundas da combinação do refino em moinho PFI com tratamentos enzimáticos. As propriedades relacionadas à resistência intrínseca da fibra, como resistência ao rasgo, apresentaram maiores incrementos em polpas oriundas da combinação dos tratamentos ultrassônicos e enzimáticos.

Palavras-chave: Reciclagem, propriedades do papel, refino, ultrassom.

\section{INTRODUCTION}

Steady expansion of the paper recycling industry attests to the growing importance of such activity in a country's economy, revealing a change in the outlook of society as more and more people have grown to accept recycled products.

Looking to significantly increase productivity and improve the quality of products launched in the market, manufacturing companies and research institutes have been investing in the development of new technologies to try and mitigate, whether partially or fully, the negative effects of previous production cycles.

Enzymatic treatment has proved to be capable of causing changes to the characteristics of fibers, there being reports of improvements to the mechanical strength properties of the resulting paper (GIL et al., 2007; MANSFIELD; DICKSON, 2001; POMMIER et al., 1990; SOUSA, 2002; STORK; PULS, 1995; TAOUAI et al., 2008; WONG; MANSFIELD, 1999). Likewise, ultrasound wave technologies are shedding new light on the subject of restoring properties of recycled paper (MANFREDI et al., 2012; MANFREDI; OLIVEIRA, 2010). Therefore, a combination of these technologies can be an alternative to the conventional production process while exploring the great potential of secondary fibers.

This study thus evaluates the capability potential of enzymatic treatments using different types of enzyme in combination with conventional mechanical refining and with ultrasonic treatments as an alternative for restoring properties of recycled paper.

\footnotetext{
${ }^{1}$ Universidade Federal de Viçosa - Viçosa, Minas Gerais, Brazil
} 


\section{MATERIAL AND METHODS}

Secondary fibers from post-consumer cardboard scrap were used to perform this study. To start with, scrap pieces in sufficient quantities to perform all treatments were hydrated for 4 hours and then processed in a pulper. The pulp was wetly homogenized in a drum and centrifuged to remove excess water, then disaggregated, placed in plastic bags and stored under refrigerated conditions $\left(4^{\circ} \mathrm{C}\right)$.

\subsection{PFI mill refining}

Conventional refining was performed on a $30 \mathrm{~g}$ oven-dry pulp sample, which was disaggregated at 3000 revolutions at around $0.8 \%$ consistency using a Regmed laboratory pulper. The pulp was then prepared at $10 \%$ consistency and refined in a PFI mill. The number of revolutions used for refining was estimated, so as to reach a maximum ${ }^{\circ} \mathrm{SR}$ value close to 55 , and then compared to the proposed alternative ultrasound refining. The refining intensity was $0,400,800$ and 1200 revolutions. Following the refining stage, the pulps were subjected to enzymatic treatments.

\subsection{Ultrasonic refining}

The ultrasonic treatment was performed by directly applying a nominal power of 190 Watts to the pulp sample. For that, $30 \mathrm{~g}$ of oven-dry pulp was disaggregated in distilled water at 3000 revolutions. Consistency was then adjusted to $3 \%$ because at this consistency, based on studies by Silva (2002), ultrasound phenomena are more effective in developing paper properties, which are for the most part dependent on external fibrillation. A mechanical stirrer was used in order to keep the pulp continually moving, that way standardizing ultrasonication in all treatments. The pulp was subjected to $0,10,20$ and 30 minutes of ultrasonication, noting that these time intervals were aimed at reaching a maximum ${ }^{\circ} \mathrm{SR}$ value close to 55 . Following ultrasonication, the pulps were subjected to enzymatic treatments.

\subsection{Enzymatic treatments}

The enzymatic treatment was performed with commercial enzymes, maintaining also a control sample in which the operating conditions had no addition of enzymes (reference).

For each repetition, $30 \mathrm{~g}$ of oven-dry pulp were used. The enzymatic treatments were performed in bain-marie, under constant stirring, and the operating conditions are described in Table 1 as per manufacturer recommendations. The pulp was subsequently rinsed in 9 liters of distilled water.

\subsection{Physical and mechanical tests}

For the physical and mechanical tests, handsheets were made using a TAPPI handsheet former (Technical Association of Pulp and Paper Industry) according to the methodology prescribed by TAPPI. At each refining level, 5 handsheets $\left(120 \mathrm{~g} / \mathrm{m}^{2}\right)$ were formed in preparation for the compression tests. The remainder of the suspension was used to determine drainage resistance (TAPPI T $248 \mathrm{~cm}-$ 85 ) and to form $60 \mathrm{~g} / \mathrm{m}^{2}$ handsheets in order to perform the other tests described in Table 2 (TAPPI 205 om-81). The handsheets were stored in an environment with a relative humidity of $50 \pm 2 \%$ and a temperature of $23 \pm 1^{\circ} \mathrm{C}$ (TAPPI 402 sp-98).

Trial tests were conducted according to standardized procedures and methodologies prescribed by the Technical Association of the Pulp and Paper Industry (TAPPI), as illustrated in Table 2.

\subsection{Statistical analysis}

After the treatments, results found were statistically analyzed by regression analysis using software application SAS (Statistical Analisys System). The resulting equations

Table 1 - Operating conditions of treatments with commercial enzymes.

Tabela 1 - Condições operacionais dos tratamentos com as enzimas comerciais.

\begin{tabular}{lccccc}
\hline Enzymes & $\mathrm{pH}$ & $\begin{array}{c}\text { Temperature } \\
\left({ }^{\circ} \mathrm{C}\right)\end{array}$ & $\begin{array}{c}\text { Reaction time } \\
(\text { hours })\end{array}$ & $\begin{array}{c}\text { Dosage } \\
(\mathrm{Kg} / \text { ton })\end{array}$ & $\begin{array}{c}\text { Consistency } \\
(\%)\end{array}$ \\
\hline Cellulase & $7.5-7.8$ & 45 & 2 & 0.50 & 4 \\
Hemicellulase & $7.5-7.8$ & 45 & 2 & 0.10 & 4 \\
Mixture 1* & $7.5-7.8$ & 45 & 2 & 0.20 & 4 \\
Mixture 2* & $6.5-7.0$ & 50 & 1 & 0.25 & 3 \\
\hline
\end{tabular}

*cellulase and hemicellulase mixtures.

Cerne, Lavras, v. 19, n. 4, p. 653-660, out./dez. 2013 
Table 2 - Analytical procedures for analysis of pulps.

Tabela 2 - Procedimentos analiticos para análise das polpas.

\begin{tabular}{lc}
\hline Test & Standard \\
\hline Drainage resistance & TAPPI 200 sp-01 \\
Tensile strength & TAPPI 494 om-96 \\
Tear resistance & TAPPI T 414 om-98 \\
Compressive strength - Ring & TAPPI 822 om-93 \\
Crush Test (RCT) & TAPPI 220 sp-01 \\
Specific bulk volume (VEA) &
\end{tabular}

were compared by the F-test, using the model identity test and adopting a 5\% significance level, according to a methodology introduced by Regazzi (1993) for linear models. Equations were compared to check for equality between them. If similar, they were reduced to a single equation. In case of a significant difference, no test was run to check which equations differed. Tested hypotheses included $\mathrm{H} 0$ : all equations are similar and can be represented by a common, reduced equation; and $\mathrm{H} 1$ : equations are statistically different and cannot be reduced to a common equation.

\section{RESULTS AND DISCUSSION}

\subsection{Physical and mechanical properties of the pulp and paper}

\subsubsection{Drainage resistance}

The combination of mechanical refining in a PFI mill with enzyme treatments provided higher values of drainage resistance, in relation to the initial, unrefined control pulp ( 0 Wh of energy consumption), as is illustrated in Figure 1. This property, being directly correlated with fines content, flexibility and interfiber bonding, indicates that the combination of ultrasonication with enzymatic treatments acts more mildly than the combination of PFI refining with enzymatic treatments.

It was found that at higher intensities $(10 \mathrm{Wh}$ onward for pulps refined in a PFI mill and 60 Wh onward for pulps subjected to ultrasound), pulps subjected to the treatments Cellulase and Mixture 1 had decreases in drainage resistance. A possible explanation for this fact is that, once fines are separated from the fiber wall and increase with intensified refining, they start to hydrolyze under the effect of enzymes and therefore fail to participate as a filling material to help increase drainage resistance. It is thus postulated that increase in the number of interfiber
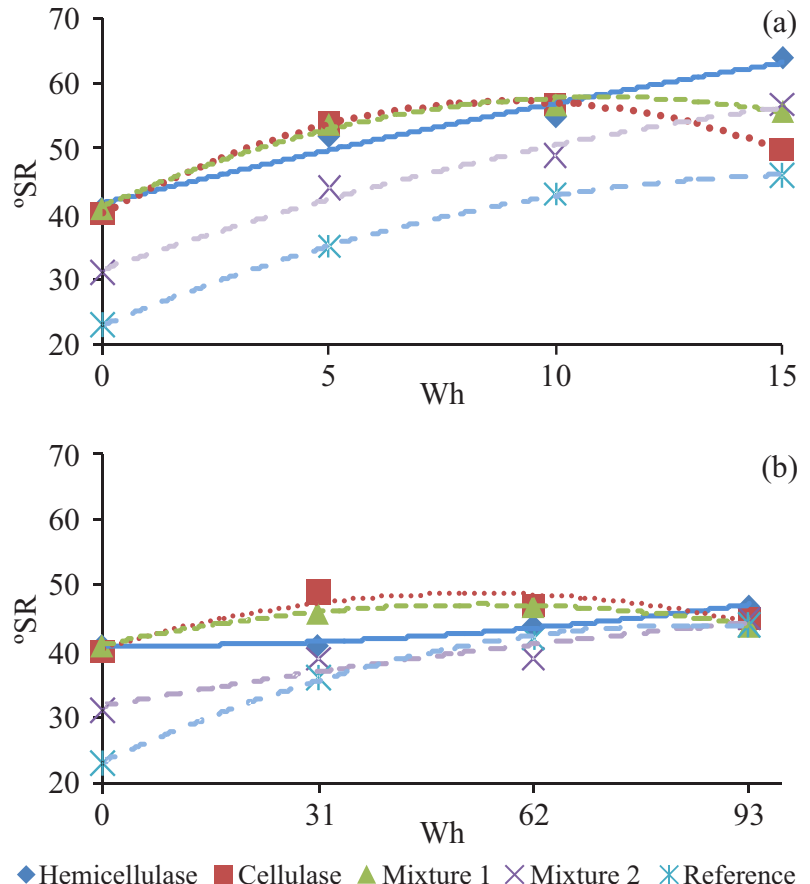

Figure 1 - Drainage resistance ( $\left.{ }^{\circ} \mathrm{SR}\right)$. a) Enzymatic treatment following PFI mill refining. b) Enzymatic treatment following ultrasonic refining.

Figura 1 - Resistência à drenagem da polpa ('SR). a) Tratamento enzimático posteriormente ao refino no moinho PFI. b) Tratamento enzimático posteriormente ao refino ultrassônico.

bonds did not suffice to compensate for the hydrolysis of fines.

Several authors observed a reduction in drainage resistance after subjecting fibers to enzymatic treatments (GIL et al., 2007; POMMIER et al., 1990; SOUSA, 2002; STORK; PULS, 1995) and associated such event with hydrolysis of fines, given their high amorphous contents.

It should be noted that the changes occurring to the pulps that reflected as a reduction in drainage resistance, due to a reduction in fines content, did not result in a reduction of other properties being assessed. The correlation between physical properties and presence of fines will depend on the type of pulp in question (SOUSA, 2002). Mohlin $(1977,1980)$ studied this correlation and found that an optimal ratio of fines will depend on the property of interest, noting that it typically ranges between a minimum value that allows resistance to increase and a maximum value from which improvement to the properties is minimal.

Cerne, Lavras, v. 19, n. 4, p. 653-660, out./dez. 2013 


\subsubsection{Tensile strength}

Figure 2 provides results of tensile strength, with enzymatic treatments following PFI refining and ultrasonic refining.
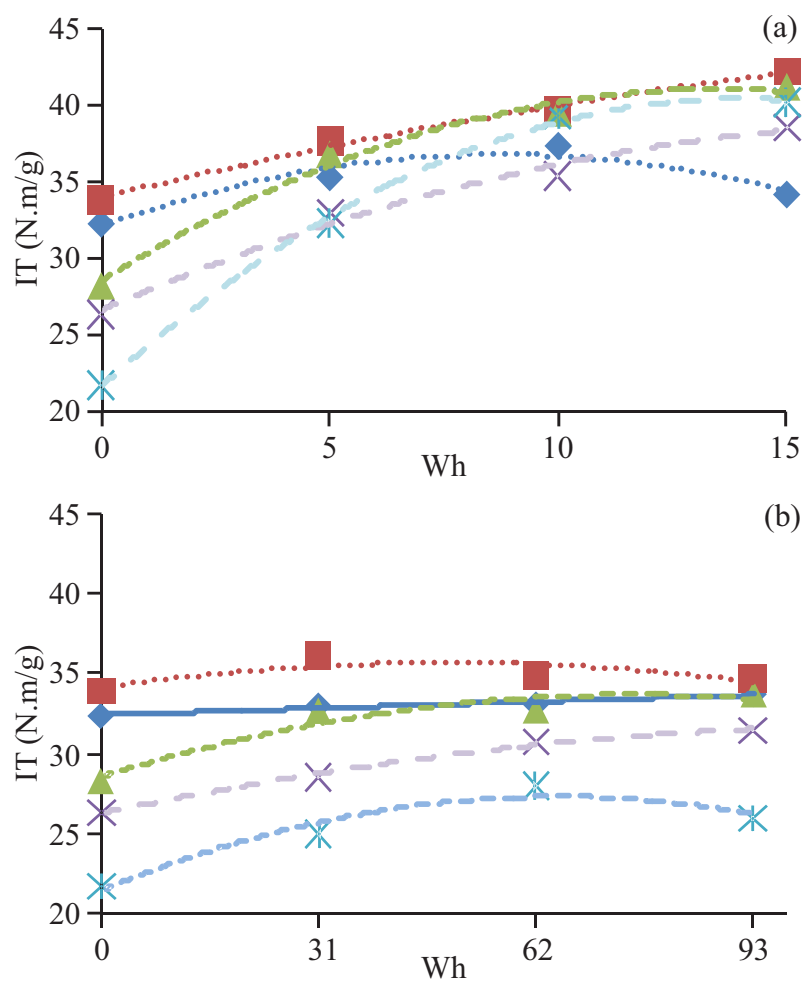

$\checkmark$ Hemicellulase Cellulase $\Delta$ Mixture $1 \times$ Mixture $2 *$ Reference

Figure 2 - Tensile index (IT). a) Enzymatic treatment following PFI mill refining. b) Enzymatic treatment following ultrasonic refining.

Figura 2 - Índice de tração (IT). a) Tratamento enzimático posteriormente ao refino no moinho PFI. b) Tratamento enzimático posteriormente ao refino ultrassônico.

The ultrasonic treatment provided smaller increases, in relation to the initial control pulp, than the PFI mill. However, when this treatment is combined with the enzymatic treatment, it provides larger increments, indicating that the small internal disarray caused by the ultrasonic treatment facilitates enzyme action.

The combination of PFI mill refining with the Cellulase enzyme treatment resulted in maximum increase of $73.76 \%$, in relation to the initial control pulp, requiring $15 \mathrm{Wh}$ of energy consumption. The combination of ultrasonic treatment with enzyme treatment resulted in a maximum increase of $66.30 \%$, with respect to the initial control pulp, requiring $31 \mathrm{Wh}$ of energy consumption when using the same enzyme.

The Hemicellulase treatment following PFI refining led to an increase of up to $71.96 \%$, in relation to the initial control pulp, requiring $10 \mathrm{Wh}$ of energy consumption. Above $10 \mathrm{Wh}$, however, a decrease of $17.65 \%$ was noted in that property in comparison with the pulp only subjected to refining at the same intensity. This could be associated with fiber brittleness as caused by increasing intensity of PFI refining, noting that this did not occur with Cellulase or with Mixtures 1 and 2.

Effects of enzymatic treatment are more noticeable when they are combined with mechanical and ultrasonic refining at lower intensities. In such cases, tensile strength tends to increase, to stabilize and to reduce with increasing refining intensity. This reduction could be associated with the occurrence of fiber brittleness.

Results in this study and literature findings (GIL et al., 2007; MANSFIELD; DICKSON, 2001; SPIRIDON; DUARTE, 2002; TAOUAI et al., 2008; WONG; MANSFIEDS, 1999) lead to the conclusion that enzymatic treatments help improve interfiber bonding and their potential increases if combined with mechanical refining and/or ultrasonication.

\subsubsection{Tear resistance}

The combination of PFI refining with the enzymatic treatments resulted in a reduction of intrinsic fiber strength, and the combination of these technologies weakened the fibrillar structure even further (Figure 3). A similar effect was found by Ganapati and Heitmann (1991) and Pala et al. (1998). The pulp treated with Hemicellulase had the greatest reduction, in relation to the reference pulp, $13.29 \%$. Although the values obtained from combining the technologies had higher indices than the initial pulp, the larger number of bonds failed to ensure maintenance of this property, demonstrating that individual fiber strength is reduced to the extent that energy consumption is intensified.

It was also found that the combination of ultrasonic treatment with the enzymatic treatments resulted in reduced indices of tear resistance. Nearly stabilized results for this property to the extent that the ultrasonic treatment was intensified reinforces the notion that this treatment does not reduce intrinsic fiber strength. It is thus postulated that a reduction in this property is directly correlated with the mechanism of enzyme action.

Cerne, Lavras, v. 19, n. 4, p. 653-660, out./dez. 2013 

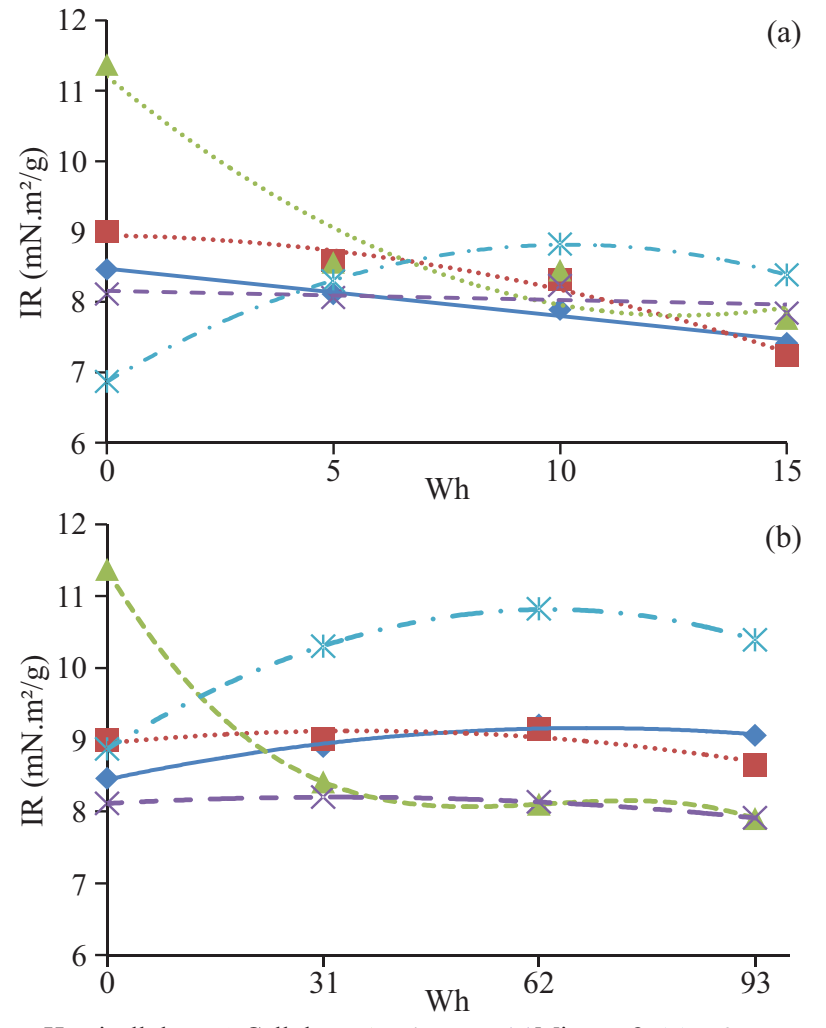

-Hemicellulase Cellulase $\Delta$ Mixture $1 \times$ Mixture $2 *$ Reference Figure 3 - Tear index (IR). a) Enzymatic treatment following PFI mill refining. b) Enzymatic treatment following ultrasonic refining.

Figura 3 - Índice de rasgo (IR). a) Tratamento enzimático posteriormente ao refino em moinho PFI. b) Tratamento enzimático posteriormente ao refino ultrassônico.

\subsubsection{Ring crush strength}

Compressive strength is one of the most important properties of papers that will later be subjected to compression and stacking, including corrugated cardboard sheets for packaging purposes (SILVA, 2011).

As was concluded for tear index, the combination of PFI mill refining with enzymatic treatments and ultrasound refining with enzymatic treatments result in reduced intrinsic fiber strength. It can thus be concluded that improvements obtained for this property are correlated with increased number of interfiber bonds.

Although tear resistance tests and ring crush resistance tests are influenced by the same fiber characteristics, they may produce different results, due to the mode and point of force application differing between them (SILVA, 2011).
Figure 4 shows that pulps subjected to the treatment with the Cellulase enzyme had greater increments, in relation to the unrefined control pulp, with maximum increases of $122.08 \%$ and $74.03 \%$ respectively combined with PFI mill refining and with ultrasonic refining.

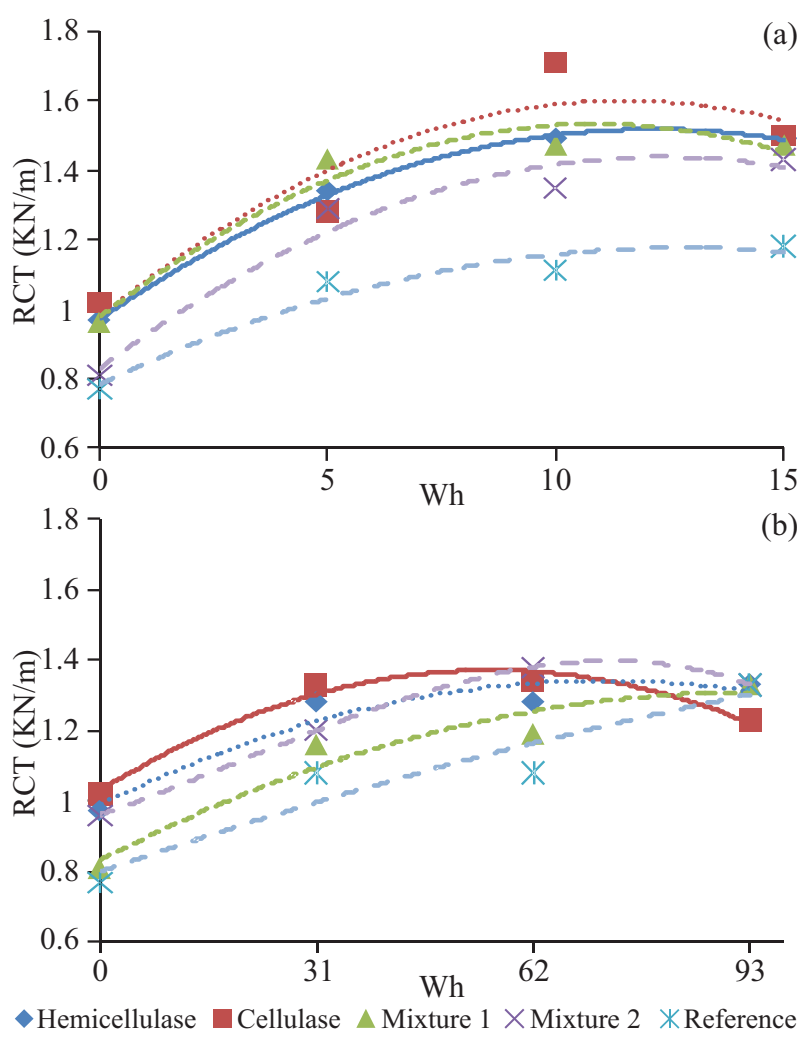

Figure 4 - Ring crush test (RCT). a) Enzymatic treatment following PFI mill refining. b) Enzymatic treatment following ultrasonic refining.

Figura 4 - Resistência ao esmagamento do anel (RCT). a) Tratamento enzimático posteriormente ao refino em moinho PFI. b) Tratamento enzimático posteriormente ao refino ultrassônico.

\subsubsection{Bulk}

As for the combination of enzymatic treatment with PFI mill refining, it seems likely that fibers were affected by the enzyme action, to a point where they collapsed from the pressure applied by the handsheet forming process (Figure 5). The bulk decreased as the refining intensity increased, on account of fiber collapse, of reduced individual fiber strength and of increased fines production. A maximum reduction of $28.97 \%$ was observed in bulk when the pulp was treated with the Cellulase enzyme.

Cerne, Lavras, v. 19, n. 4, p. 653-660, out./dez. 2013 

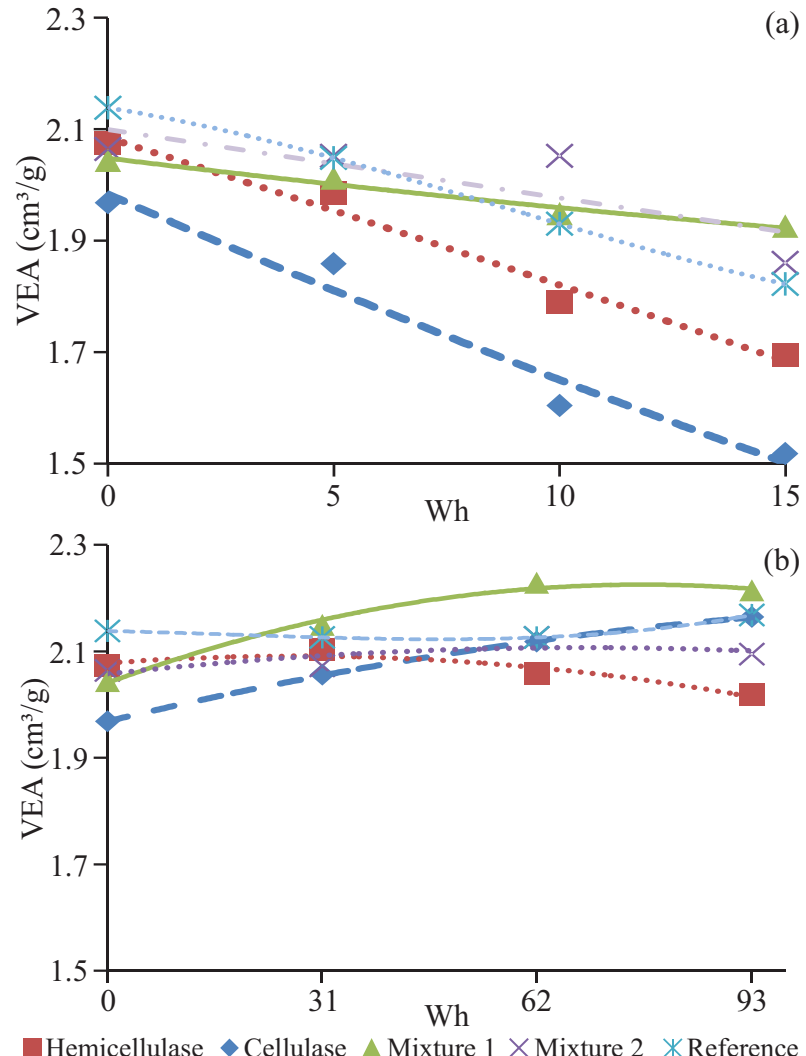

Figure 5 - Bulk (VEA). a) Enzymatic treatment following PFI mill refining. b) Enzymatic treatment following ultrasonic refining.

Figura 5 - Volume especifico aparente (VEA). a) Tratamento enzimático posteriormente ao refino no moinho PFI. b) Tratamento enzimático posteriormente ao refino ultrassônico.

The ultrasonic treatment reduced the bulk of the paper only at high intensity, increasing the fines content in the pulp. Under less intense conditions, the specific bulk volume was increased by ultrasound action, as results illustrate. A maximum increase of $4.21 \%$ was observed in the bulk when the pulp was treated with Mixture 1 enzyme.

The increase in bulk observed here, and by Silva and Oliveira (2002), could be related to cavitation. Increased viscosity reduces the likeliness of cavitation bubbles forming and retards the energy propagation from their implosions. Therefore, it can be concluded that a more consistent suspension is less likely to suffer the effect of cavitation, which apparently impairs fiber swelling, whereas in a suspension with less viscosity the indirect effect of waves on the fibers appears to be, in this respect, more effective. A reduction in the nominal power of the device is directly related to the amplitude of ultrasonic waves, which in turn affect the way cavitation bubbles are formed.

Results found in this study revealed that both the combination of PFI mill refining with enzymatic treatments and the combination of ultrasonication with enzymatic treatments are capable of developing the properties of recycled paper. And, based on the F-test, the hypothesis of equality for the five equations was rejected, both for pulps refined in a PFI mill and for pulps subjected to ultrasound, regarding all physical and mechanical properties, which leads to the conclusion that there are significant differences $(\mathrm{P}<0.05)$ between the treatments.

The combination of enzymatic treatments with PFI mill refining causes intenser changes to fibrillar structures and thus enables greater increases in flexibility, collapsibility and in fiber surface area, reducing handsheet porosity while improving fiber network conformability. Consequently, this combination promotes greater increments in the properties that depend on interfiber bonding, if compared with the combination of enzymatic treatments with ultrasonication, whereas the latter enables increments in relation to the initial pulp and superior gains relative to the first combination in the properties that depend on intrinsic fiber strength.

Although the enzyme Mixture 2 showed increases in relation to the reference sample, both for PFI mill and for ultrasound pulps, overall the performance of this enzyme was poorer than that of the other enzymes. This effect could be related to the time of treatment fibers had been subjected to with this enzyme (half the time used by other enzymes).

Two situations can be defined when it comes to combined use of enzymes and PFI refining or ultrasound. In the first, refining could be kept at a constant level (maintaining the energy consumption applied), thus gain in terms of physical and mechanical strength of the paper. In the second, paper specifications could be kept constant, that way leading to a reduction in the energy required by refining operations. Both situations offer significant advantages, the first enables improved end product quality whereas the second offers clear advantage in reducing production costs. Another aspect to be taken into account is that, where a good result is attained in ultrasonic and/or conventional refining, use of enzymes could potentially reduce the requirement for additives such as starch.

Cerne, Lavras, v. 19, n. 4, p. 653-660, out./dez. 2013 


\section{CONCLUSIONS}

Results found in this study led to the following conclusions:

- both the combination of PFI mill refining with enzymatic treatments and the combination of ultrasound with enzymatic treatments were effective in enhancing the properties of recycled paper derived from post-consumer scrap;

- properties relating to interfiber bonding such as tensile index and ring crush strength had greater increases, in relation to the initial pulp, in pulps derived from the combination of PFI mill refining with enzymatic treatments;

- the combination of ultrasonication with enzymatic treatments acts more mildly than the combination of PFI mill refining with enzymatic treatments;

- properties relating to intrinsic fiber strength such as tear index and bulk had greater increases in pulps derived from the combination of ultrasonication with enzymatic treatments;

- overall, the Cellulase enzyme was more effective in improving paper properties.

\section{REFERENCES}

GANAPATI, R. B.; HEITMANN, J. L. Novel techniques for enhancing the strength of secondary fibre. Tappi Jounal, Atlanta, v. 74, n. 9, p. 151-157, Sept. 1991.

GIL, N.; GIL, C.; AMARAL, M. E.; COSTA, A. P.; DUARTE, A. P. Biorefinação: uso de enzimas no melhoramento do refinamento de uma pasta Kraft branqueada de Eucalyptus globulus. In: ENCONTRO NACIONAL TECNICELPA, 20., 2007, Tomar. Anais... Tomar: Tecnicelpa, 2007. p. 7-13.

MANFREDI, M.; OLIVEIRA, R. C.; SILVA, J. C. Melhoramento das propriedades de papéis reciclados através da ultrassonificação das fibras e adição de xilanas. Revista Árvore, Viçosa, v. 36, n. 4, p. 777-785, abr. 2012.

MANFREDI, M.; OLIVEIRA, R. C. Aplicação de tratamento ultrassônico da polpa e adição de xilanas na indústria de fibras secundária. In: ENCONTRO NACIONAL DA TECNICELPA, 31., 2010, Lisboa. Anais... Lisboa: TECNICELPA, 2010. 1 CD-ROM.

MANSFIELD, S. D.; DICKSON, A. R. The effect of selective cellulolytic treatments of softwood kraft pulp on sheet consolidation. Appita Journal, Victoria, v. 54, n. 2, p. 239244, Mar. 2001.

MOHLIN, U. B. Mechanical pulp properties: the importance of fines retention. Svensk Papperstidning, Stockholm, v. 80, n. 3, p. 84-88, 1977.

MOHLIN, U. B. Properties of TMP fractions and their importance for the quality of printing papers: part 1, large variations in properties within fractions are observed. Svensk Papperstidning, Stockholm, v. 83, n. 18, p. 513-519, 1980.

PALA, H.; MOTA, M.; GAMA, F. M. Effects of enzymatic treatment and refining on the properties of recycled pulp. In: ENCONTRO TECNICELPA, 16., 1998, Covilhã. Anais... Covilhã: Tecnicelpa, 1998. 1 CD-ROM.

POMMIER, J. C.; GOMA, G.; FUENTES, J. L.; ROUSSET, C. Using enzymes to improve the process and the product quality in the recycled paper industry: part 2, industrial applications. Tappi Journal, Atlanta, v. 73, n. 12, p. 197-202, Dec. 1990.

REGAZZI, A. J. Teste para verificar a identidade de modelos de regressão e a igualdade de alguns parâmetros num modelo polinomial ortogonal. Revista Ceres, Viçosa, v. 40, n. 228, p. 176-195, 1993.

SILVA, J. C. Aplicação de enzimas, extração e adição de hemiceluloses combinadas com ondas ultrassônicas para desenvolvimento de propriedades de papéis reciclados. 2011. 184 p. Dissertação (Mestrado em Ciência Florestal) Universidade Federal de Viçosa, Viçosa, 2011.

SILVA, R. P. Utilização de vibrações ultra-sônicas para o refino de celulose Kraft de eucalipto. 2002. 88 p. Tese (Doutorado em Ciência Florestal) - Universidade Federal de Viçosa, Viçosa, 2002.

SILVA, R. P.; OLIVEIRA, R. C. Vibrações ultra-sônicas: uma alternativa tecnológica ao refino da celulose kraft de eucalipto. In: CONGRESSO E EXPOSIÇÃO ANUAL DA ABTCP, 35., 2002, São Paulo. Anais... São Paulo: ABTCP, 2002. 1 CDROM.

SOUSA, H. M. P. D. Aplicação de celulases e xilanases na reciclagem de fibras de papel. 2002. 409 p. Dissertação (Mestrado em Engenharia Química e Biológica) Universidade do Minho, Braga, 2002.

Cerne, Lavras, v. 19, n. 4, p. 653-660, out./dez. 2013 
SPIRIDON, I.; DUARTE, A. P. Some preliminary data on enzymatic hydrolysis of pinus pinaster kraft pulp. In: CONGRESO IBEROAMERICANO DE INVESTIGATIÓN EN CELULOSA Y PAPEL, 2., 2002, Campinas. Anais... Campinas: CIADICYP, 2002. 1 CD-ROM.

STORK, G.; PULS, J. Change in properties of different recycled pulps by endoglucanase treatment. In: INTERNATIONAL CONFERENCE ON BIOTECHNOLOGY IN THE PULP AND PAPER INDUSTRY, 6., 1995, Vienna.

Proceedings... Vienna: ICB, 1995. p. 145-150.
TAOUAI, H.; SACON, V. M.; RODRIGUES, M. S. da. $\mathrm{O}$ uso de enzimas no refino de polpa kraft branqueada de eucalipto. In: SEMINÁRIO SOBRE CELULOSE E PAPEL: BIORREFINARIA E BIOTECNOLOGIA E SEUS IMPACTOS NA INDÚSTRIA DE CELULOSE, 3., 2008, Viçosa, MG. Anais... Viçosa: UFV/LCP, 2008. 1 CD-ROM.

WONG, K. K. Y.; MANSFIELD, S. D. Enzymatic processing for pulp and paper manufacture: a review. Tappi Journal, Atlanta, v. 52, n. 6, p. 409-418, Nov. 1999.

Received: April 11, 2011; accepted: May 24, 2013.

Cerne, Lavras, v. 19, n. 4, p. 653-660, out./dez. 2013 